\title{
Feeding habits of Tinfoil barb, Barbonymus schwenenfeldii in the Tasik River, South Labuhanbatu, North Sumatra, Indonesia
}

\author{
DESRITA $^{1, \boldsymbol{\nu}}$, FANNI K. HASUGIAN ${ }^{1}$, ERI YUSNI $^{1}$, VINDY R. MANURUNG ${ }^{1}$, RIDAHATI RAMBEY $^{2}$ \\ ${ }^{1}$ Department of Aquatic Resources Management, Faculty of Agriculture, Universitas Sumatera Utara. Jl. Prof. A. Sofyan No. 3, Medan 20155, North \\ Sumatra, Indonesia. Tel./fax.: +62-61-8213236, "email: desrita@usu.ac.id. \\ ${ }^{2}$ Department of Forestry, Faculty of Forestry, Universitas Sumatera Utara. Jl. Tri Darma Ujung No. 1, Medan 20155, North Sumatra, Indonesia
}

Manuscript received: 7 February 2021. Revision accepted: 30 March 2021.

\begin{abstract}
Desrita, Hasugian FK, Yusni E, Manurung VR, Rambey R. 2021. Feeding habits of Tinfoil barb Barbonymus schwenenfeldii in the Tasik River, South Labuhanbatu, North Sumatra, Indonesia. Biodiversitas 22: 2131-2135. Research on feeding habits of Tinfoil barb, Barbonymus schwanenfeldii was carried out in the Tasik River from July to August 2020. This study aims to determine the composition of foods consumed by Tinfoil barb fish, and the availability of natural food in the Tasik River from 3 sampling stations. Fishes were caught using a gillnet with a mesh size of $3.18 \mathrm{~cm}$, then the fish samples were dissected, and the digestive tract was taken and preserved with $10 \%$ formalin. A total of 138 Tinfoil bars were caught for this study. Analysis of stomach contents found that Tinfoil barb ate phytoplankton (41-48\%) as the primary food, moss (25-38\%), plant pieces (13-17\%), worms (2-11\%) as a complementary food and few of insects (0-4\%), zooplankton (0-1\%) as other foods. Based on analysis of food item values, all types of food and ratio within the intestine length and the total length showed that Tinfoil Barb was classified as omnivorous. The availability of natural foods for Tinfoil Barb in the Tasik River consists of the genera Asteroinella, Bacillaria, Bidulphia, Cestom, Gyrosigma, Gonatozygon, Oscillatoria, and Thalassiora.
\end{abstract}

Keywords: Barbonymus schwenenfeldii, feeding habits, omnivorous, Tasik River,Tinfoil barb

\section{INTRODUCTION}

Indonesia is the second-highest biodiversity country in terms of fish species richness after Brazil (Muchlisin and Azizah 2009). About 1300 species of freshwater fish in Indonesia are mostly found in the river (Desrita et al. 2018; Desrita et al 2020). Freshwater fish species in Asia are dominated by the Cyprinidae fish group (Nguyen and De Silva 2006). Tinfoil barb (B. schwanenfeldii) is one of the freshwater fish found in the Tasik River. The local name is often referred as kapiek, lempam, lempem, lampam, tenadak, tengadak, and labosang fish. Tinfoil barb is prevalent because it has good taste and fast growth (Ismail et al. 2019). In nature, it can reach large sizes (34 cm long and weighing more than $500 \mathrm{~g} /$ fish) even fish with $45 \mathrm{~cm}$ length are also found (Farida et al. 2016) in rivers and lakes (Setiawan 2007).

The characteristics are shown by flat and widened body shape with silver and golden yellow body, a red dorsal fin with black patches on the tips, red pectoral, pelvic and anal fins, and an orange tail fin black-white outline along the fin tail. Rib line with 35-36 rib line scales, and 13 scales before the dorsal fin and lateral line (Aisyah et al. 2017). Variations in the head, especially the mouth's shape, lead to modifications in eating habits (Kenthao and Jearranaiprepame 2020).

Tinfoil barb has a wide distribution in Southeast Asia, including significant rivers in mainland Asia to Sumatra and Kalimantan islands in Indonesia. According to Kottelat et al (1993), Tinfoil barb distribution is spread from
Sumatra, Borneo, Malaya, and Indochina. While Tinfoil Barb found around the Tasik River. As one of the tributaries, the Tasik River has a big potential for fisheries resources, and used by the surrounding community for various activities such as disposal of agricultural waste, household waste, and fishing. The riverbed is generally formed by rock, gravel, and sand substrate, transparent watercolor, slow to fast water flow, and the river is surrounded by the forest (Haryono and Subagja 2008). Human activities around this river may not only affect the lives of organisms that live in the waters but also affect the fish populations in relation to the food chain. Therefore, it is necessary to create good management so that Tinfoil barb can be used optimally and remain sustainable. To support this goal, a series of studies are needed, including identifying the type of feeds they consumed.

Food is a significant component in the growth and development of fish. Feeding habits are the quantity and quality of food eaten by fish, while it is defined as the time, place, and how fish obtain the food in waters (Effendie 2002). One of the ways to know the natural food of fish is through their feeding habits in nature. Fish of the same type but live in different waters will have different feeding habits (Gunawan et al. 2017). The types of natural food that fish eat vary widely, depending on the type of fish, age level, and the habitat in which the individual fish species are present. one of the natural foods is phytoplankton. Phytoplankton from the diatoms type is a type of natural food when the fish starts its life, but after the fish reaches 
adulthood, the type of natural food eaten will change according to the parent's food habits (Pulungan et al. 2007).

One of the vital information from the study of feeding habits is we can find out the composition of food in the stomach of the fish as the primary food, side food, and other foods, and some factors that determine whether a fish species is willing to eat an organism can be predicted by the food size, food availability, water temperature, and the physiological conditions of the fish (Asriansyah 2008).

Knowledge of fish-feeding habits can also help to select fish species (Mondol et al. 2005). Information about feeding habits of fish in their natural habitat is essential to support the domestication process and to develop technology for feeding practices to support aquaculture (Muchlisin et al. 2015). By knowing the type of Tinfoil Barb food in the Tasik River, a form of management can be formulated in maintaining the sustainability of Tinfoil Barb in the Tasik river in the future. This study aims to determine the composition of the type of fish feed, the fish's active time to eat, and the types of natural food in the Tasik River.

\section{MATERIALS DAN METHODS}

\section{Study area}

This research was conducted from July to August 2020 in the Tasik River, South Labuhanbatu, North Sumatera Province (Figure 1). Fish sample identification was carried out at the Plant Tissue Culture Laboratory, Faculty of Mathematics and Natural Sciences, USU, Indonesia.

\section{Collection and processing of fish samples}

Fish samples were caught using the gillnet with a mesh size of $3.18 \mathrm{~cm}$. Sampling was carried out alternately from 3 stations, started from Station 1 and ended at Station 3. Sampling was carried out 3 (three) times in 2 months. Gillnet mounted in the afternoon at $18.00 \mathrm{pm}$ and then lifted in the morning at $05.00 \mathrm{am}$, it is done for 3 times retrieval. Then the fish caught are taken one by one and processed. The caught fish were weighed and measured for their total length, then carefully dissected from the dorsal to the ventral, then a sample of the fish digestive tract was taken and then put into a sample bottle and given $10 \%$ formalin. Each sample bottle is labeled with description.

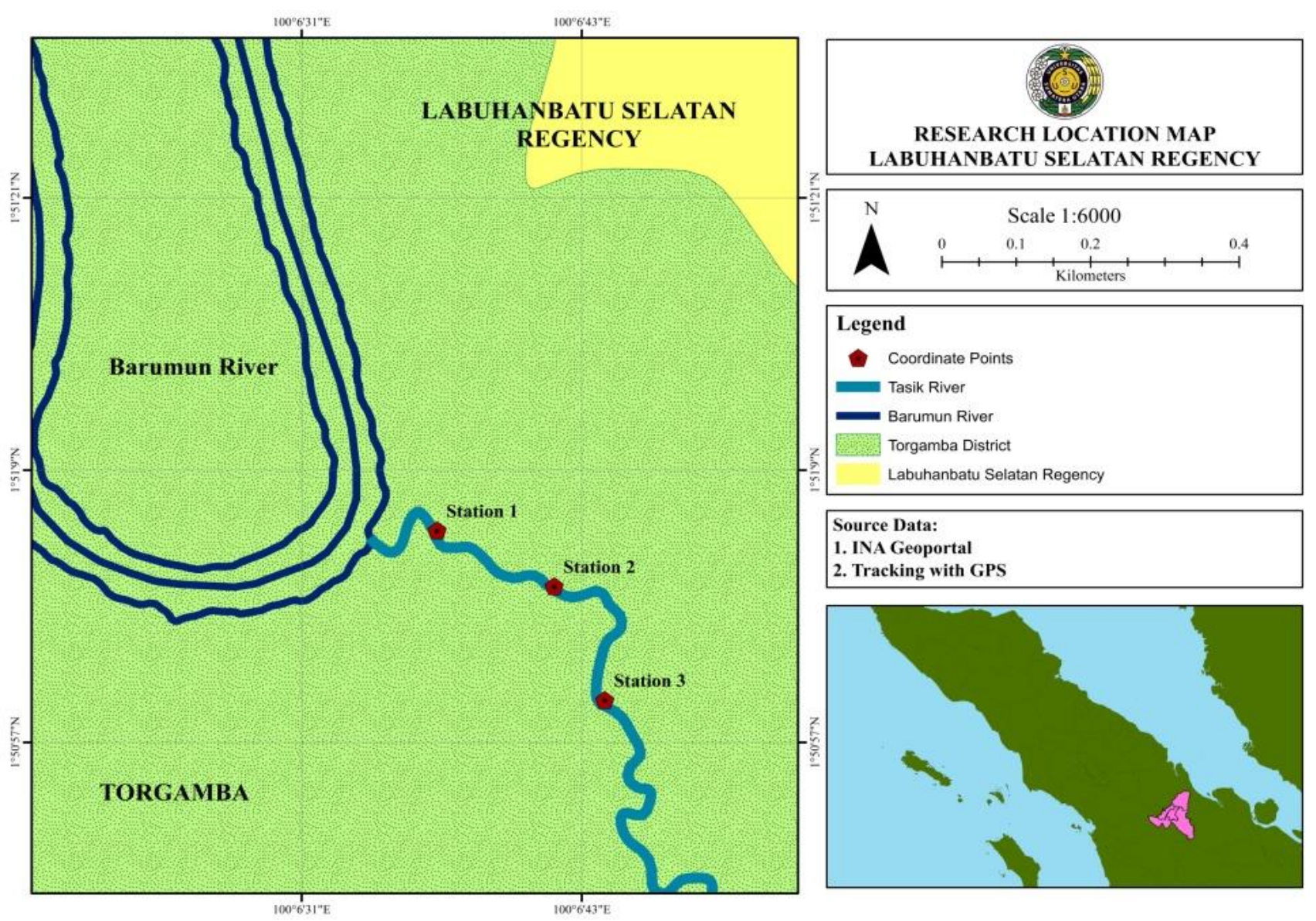

Figure 1. Research Sites (Station 1: $01^{\circ} 51^{\prime} 55.0^{\prime \prime} \mathrm{LU} 100^{\circ} 06^{\prime} 49.3^{\prime \prime} \mathrm{E}$, Station 2: $01^{\circ} 51^{\prime} 03.6^{\prime \prime} \mathrm{LU} 100^{\circ} 06^{\prime} 42.0^{\prime \prime} \mathrm{E}$ and Station 3: $\left.01^{\circ} 50^{\prime} 58.5^{\prime \prime} \mathrm{LU} 100^{\circ} 06^{\prime} 44.2^{\prime \prime} \mathrm{E}\right)$ 
In the laboratory, fish intestines were washed with tape? water and placed on a paper towel to absorb the water and dried in the air for 5 minutes. Then the food that is in the stomach is taken by carefully opening the stomach using a surgical instrument (Rayhanu et al. 2004). The digestive organs that still have contents are weighed then the volume and length of the digestive tract are measured. Then the contents are removed, separated into a petri dish, then the empty digestive organs are weighed again. Then the filled stomach is reduced and the stomach is empty to determine the weight of the stomach contents. To measure the volume of food is done by placing the stomach contents in a measuring cup containing $5 \mathrm{~mL}$ of distilled water. The increase in volume in the measuring cup is the volume of food (Rayhanu et al. 2004). Then counting each organism found in the stomach of the fish. For organisms that cannot be seen with the eye can be identified with a microscope. Dilute the stomach contents with $5 \mathrm{~mL}$ of distilled water. Each drop of sample was observed under a microscope and analyzed, then identified using Yamaji's (1979) identification book. For the analysis of stomach contents, three drops were taken for one fish sample. Analysis of the contents of the digestive tract was carried out to determine the composition of fish feed.

\section{Collection and identification of plankton}

Water samples were taken at each station with one repetition using a monofilament plankton net with a mesh size of $40 \mu \mathrm{m}$. Sampling was carried out in river bodies. The water is filtered into the plankton net, then the edges of the plankton net are sprayed with distilled water, then the filtered water in the $200 \mathrm{~mL}$ sample bottle is given 3-5 drops of Lugol and labeled. Sample identification was carried out using a microscope. A few drops of water in the sample bottle are taken using a dropper then placed on the preparation and covered with a glass cover. Then sample identification was carried out based on Yamaji's (1979) identification book.

\section{Data analysis}

The stomach content index was analyzed by comparing the total fish weight with the stomach contents weight. The value obtained is expressed in percent. The fish stomach content index can be determined using the following formula:

$$
\operatorname{ISC}(\%)=\frac{S C W}{B W} \times 100
$$

Where:

SCW : Weight of stomach contents (grams)

BW : Bodyweight (grams)

The relative length of the fish gut (Relative length of the gut / RLG), calculated with the formula: (Nurfadila et al. 2019)

$$
\operatorname{RGL}(\%)=\frac{\text { Instestinal length }(\mathrm{mm})}{\text { Total Body Lenght }(\mathrm{mm})}
$$

The relative gut length for carnivorous fish is 1 , omnivorous fish is between 1-3, while for herbivorous fish is > 3. (Syahputra et al. 2014).

Analysis of the type of food use Index of Prepoderance which is a combination of the frequency of occurrence method and volumetric method with the following formula: (Rayhanu et al. 2004)

$$
\mathrm{IP}=\frac{V i X O i}{\sum V i X O i} X 100 \%
$$

Where:

IP : Index of Preponderance

$\mathrm{Vi}$ : Percentage of the volume food kind one

$\mathrm{O}_{\mathrm{i}}$ : Percentage of the frequency of occurrence of one food type

Organisms found in the digestive tract were identified based on the percentage of food criteria as follows:

$$
\begin{aligned}
& \text { IP> 40\% : Main food } \\
& \text { IP <4\% : Additional food } \\
& \text { IP 4- 40\%: Complementary food }
\end{aligned}
$$

\section{RESULTS AND DISCUSSION}

\section{Relative Length of Intestine (RGL)}

The results of the measurement of intestinal length and body length showed that the Tinfoil Barb fish's intestinal length was twice the total body length (Table 1). This indicates that the Tinfoil Barb fish was classified as omnivorous. As Syahputra et al. (2014) stated that the relative gut length for carnivorous fish is 1 , while for omnivorous fish is between $1-3$, and for herbivorous fish is $>3$. Furthermore, Haloho (2008) stated that herbivorous fish has a long intestine, that is longer than the total body length. Whereas the intestinal length of carnivorous fish is shorter or almost equal to the total body length. In contrast, the intestinal length of omnivorous fish is only slightly longer than the total body length.

\section{Feeding habits and food items}

The preponderance analysis index aims to determine the main dietary components of Tinfoil Barb fish digestive tract by combining the frequency of occurrence method with the volumetric method. The observation results showed that the most dominant type of feed is phytoplankton from station 1 to station 3 . The frequency of occurrence of Tinfoil Barb fish food can be seen in Table 2.

The volumetric method aims to determine the volume of a type of food in the fish digestive tract. The type of food with the highest volume is phytoplankton, where the highest volumetric value is at station 2 , which is $44.7 \%$. The fish volumetric can be seen in Table 3 .

Based on the IP value (Table 4), it showed that phytoplankton was the main food of Tinfoil Barb fish (40.6-48.3\%) at all sampling locations, while mosses (25.3$38.4 \%$ ), worms (2.1-10.4\%), and plant pieces (13.2-16.7\%) as complimentary food, insects (0-4.6\%) and zooplankton $(0.3-0.7 \%)$ as other food. Setiawan (2007) stated that eating habits describe the main food, complimentary food, 
supplementary food, and substitute food for fish quantitatively. Rayhanu et al (2004) said that IP $>40 \%=$ Main Food, IP $<4 \%=$ Additional Food and IP $4-40 \%=$ Complementary Food.

The highest IP was found in the type of phytoplankton food at each observation station (40.6-48.3\%), which means that the main food for Tinfoil Barb fish in the Tasik River is phytoplankton. This is same as the research conducted by Rahyanu et al. (2004) in the Kampar River that the main food of Tinfoil Barb fish is phytoplankton, while complimentary foods is plant parts, and additional food is the animal pieces, zooplankton, and nematodes. Meanwhile, Gunawan et al. (2017) stated that grasses are the main food for Tinfoil Barb fish at all sampling locations, while worms and moss are complementary foods, insects, and seeds are additional food. The difference in food in different waters is presumably because of the food availability in different environments. In this case, it can be said that Tinfoil Barb fish are omnivorous. Hadisusanto et al. (2000) categorized Barbonymus fish as omnivores and tended to be herbivores.

The analysis results from the three research stations can be concluded that there are not many differences in food.
This is presumably due to relatively similar water conditions, and all stations are surrounded by oil palm plantations. Hinz et al. (2005) stated that the habit of using and choosing feed is related to the availability of feed in the waters, which is caused by changes in the aquatic environment.

\section{Availability of plankton natural feed in the Tasik River}

Based on the results of the analysis of the Tasik River water samples, it was found that the Bacillariophyceae class consisted of 4 genera, namely Bacillaria, Asteroinella, Bidulphia, Fragillaria from the Coscinodiscuscophyceae class consisting of 1 genus, Thalasiorra, Cyanophycea class consisting of 1 genus, namely Oscillatoria, Chrysophyceae class consisting of genus Gyrosigma, the Chlorophyceae class consists of the genus Gonatozygon and the Monogonanta class consists of the genus Cestum. It can be seen that the Bacillariophyceae class dominates the other classes, which consists of 4 genera. As Wulandari (2009) stated that the Bacillariophyceae class can adapt to existing environmental conditions; this class is cosmopolitan and has high tolerance and adaptability. The availability of natural food in the Tasik River can be seen in the following Table 5.

Table 1. Relative length of intestine (RGL) of Tinfoil barb Fish (Barbonymus schwanenfeldii) at Tasik River, North Sumatra, Indonesia

\begin{tabular}{cccccc}
\hline Station & $\begin{array}{c}\text { Total length } \\
(\mathbf{m m})\end{array}$ & $\begin{array}{c}\text { Length of intestine } \\
(\mathbf{m m})\end{array}$ & Average total length & Average length of intestine & $\begin{array}{c}\text { RGL } \\
(\%)\end{array}$ \\
\hline 1 & $69-134$ & $110-320$ & 93.69 & 189.38 & 2.07 \\
2 & $81-137$ & $130-270$ & 94.39 & 187.93 & 1.9 \\
3 & $68-143$ & $100-360$ & 88.35 & 176.5 & 1.9 \\
\hline
\end{tabular}

Table 2. Food occurrence frequency of Tinfoil Barb fish (Barbonymus schwanenfeldii)

\begin{tabular}{|c|c|c|c|c|c|c|}
\hline \multirow{2}{*}{ Types of food } & \multicolumn{2}{|c|}{ Station $1(\mathrm{~N}=52)$} & \multicolumn{2}{|c|}{ Station $2(N=46)$} & \multicolumn{2}{|c|}{ Station $3(N=40)$} \\
\hline & $\mathbf{N}$ & Oi $(\%)$ & $\mathbf{N}$ & Oi $(\%)$ & $\mathbf{N}$ & Oi (\%) \\
\hline Phytoplankton & 32 & 61.5 & 18 & 39.1 & 21 & 52.5 \\
\hline Zooplankton & 3 & 5.8 & 3 & 6.5 & 4 & 10.0 \\
\hline Mosses & 26 & 50.0 & 31 & 67.4 & 15 & 37.5 \\
\hline Plant pieces & 17 & 32.7 & 15 & 32.6 & 18 & 45.0 \\
\hline Insect pieces & 4 & 7.7 & 1 & 2.2 & 5 & 12.5 \\
\hline Worms & 10 & 19.2 & 12 & 26.1 & 6 & 15.0 \\
\hline
\end{tabular}

Table 3. Volumetric type food of Tinfoil Barb fish (Barbonymus schwanenfeldii)

\begin{tabular}{lccc}
\hline \multicolumn{1}{c}{ Type of food } & St. 1 (\%) & St.2 (\%) & St. 3 (\%) \\
\hline Phytoplankton & 28.3 & 44.7 & 31.0 \\
Zooplankton & 2.0 & 3.0 & 2.5 \\
Mosses & 33.1 & 20.1 & 33.1 \\
Plant pieces & 17.3 & 17.0 & 14.0 \\
Insect pieces & 3.9 & 0.8 & 14.0 \\
Worms & 15.4 & 14.4 & 5.4 \\
\hline
\end{tabular}

Table 4. Index of Prepoderance (IP) of Tinfoil Barb fish (Barbonymus schwanenfeldii)

\begin{tabular}{lccc}
\hline \multirow{2}{*}{\multicolumn{1}{c}{ Type of food }} & \multicolumn{3}{c}{ IP (\%) } \\
\cline { 2 - 4 } & Station 1 & Station 2 & Station 3 \\
\hline Phytoplankton & 40.6 & 48.3 & 43 \\
Zooplankton & 0.3 & 0.5 & 0.7 \\
Mosses & 38.4 & 25.3 & 32.8 \\
Plant pieces & 13.2 & 15.4 & 16.7 \\
Insect pieces & 0.7 & 0 & 4.6 \\
Worms & 6.9 & 10.4 & 2.1 \\
\hline
\end{tabular}


Table 5. Availability of plankton natural feed in the Tasik River, North Sumatra, Indonesia

\begin{tabular}{ll}
\hline \multicolumn{1}{c}{ Class } & \multicolumn{1}{c}{ Genera } \\
\hline Bacillariophyceae & Bacillaria \\
& Asteroinella \\
& Bidulphia \\
& Fragillaria \\
Coscinodiscuscophyceae & Thalasiorra \\
Cyanophyceae & Oscillatoria \\
Chrysophyceae & Gyrosigma \\
Chlorophyceae & Gonatozygon \\
Monogonanta & Cestum \\
\hline
\end{tabular}

In conclusion, Tinfoil barb fish (B. schwanenfeldii) caught in the Tasik River have a food composition consisting of phytoplankton as the primary food, mosses, worms, and plant pieces as complementary foods, insects, and zooplankton as other food. The fish were categorized as omnivore and actively foraging at night (nocturnal). The natural feed availability for Tinfoil Barb fish in the Tasik River was from the genus Asteroinella, Bacillaria, Bidulphia, Cestom, Gyrosigma, Gonatozygon, Oscillatoria, and Thalassiora.

\section{ACKNOWLEDGEMENTS}

This research was funded by the Universitas Sumatera Utara through the TALENTA grant with number 63/UN5.2.3.1/PPM/SPP-TALENTA USU/2020. We would like to thank fishermen in Kampung Jawa, Labuhanbatu Selatan for their assistance during this research in the field.

\section{REFERENCES}

Aisyah S, Bakti D, Desrita. 2017. Growth patterns and condition factors for Tinfoil barb fish (Barbodes schwanenfeldii) in the Deli Serdang River, North Sumatra Province. Acta Aquatica 4 (1): 8-12. DOI: 10.29103/aa.v4i1.317. [Indonesian]

Asriansyah A. 2008. Food habits of Sepatung fish (Pristolepis grooti) in the Musi River Basin, South Sumatra. Faculty of Fisheries and Marine Sciences, Bogor Agricultural University, Bogor. [Indonesian]

Desrita, Muhtadi A, Tamba IS, Ariyanti J, Sibagariang RT. 2018. Community structure of nekton in the upstream of Wampu Watershed, North Sumatra, Indonesia. Biodiversitas 19 (4): 13661374. DOI: $10.13057 /$ biodiv/d190424.

Desrita, Muhtadi A, Leidonald R, Sibagariang RD, Nurfadillah. 2020 Biodiversity of nekton in Batangtoru River and its Tributaries in North Sumatera, Indonesia. Biodiversitas 21 (6): 2344-2352. DOI: $10.13057 /$ biodiv/d210602.

Effendie MI 2002. Fisheries Biology. Pustaka Nusatama Foundation, Yogyakarta. [Indonesian]

Farida, Rahardjo EI, Sahrio M. 2016. The effect of several types of natural feed on growth and survival of Tengadak fish larvae (Barbonymus Schwanenfeldi). Ruaya J 4 (2): 1-6. [Indonesian]
Gunawan RH, Muchlisin ZA, Melissa S. 2017. Food habit of Lemeduk fish (Barbonymus Schwanenfeldii) in the Tamiang River, Sekerak District, Aceh Tamiang Regency, Aceh Province. Unsyiah Mar Fish Stud Sci J 2 (3): 379-388.

Hadisusanto S, Tussanti I, Trijoko. 2000. Fish communities in the Serayu River Hulu Wonosobo, Central Java. Proceedings of the National Seminar on Fish Biodiversity. Jakarta, 6 June 2000. [Indonesian]

Haloho LMB. 2008. Food Habits of Betok Fish (Anabas testudineus) in the Swamp Area of the Mahakam River, Kota Bangun, Kutai Kertanegara, East Kalimantan. [Hon. Thesis]. Bogor Agricultural University, Bogor. [Indonesian]

Haryono, Subagja J. 2008. The population and habitat of Tambra fish, Tor tambroides (Bleeker, 1854) in Muller Mountain waters Central Kalimantan. Biodiversitas 9 (4): 306-309. DOI: 10.13057/biodiv/d090414.

Hinz H, Kroncke I, Ehrich S. 2005. The feeding strategy of dab Limanda limanda in the Southern North Sea: Linking stomach contents to prey availability in the environment. J Fish Biol 67 (1): 125-145. DOI: 10.1111/j.0022-1112.2005.00918.x.

Ismail MA, Kamaruddin MS, Syukri F, Ain SN, Latif K. 2019. Changes in the mouth morpho-histology of hybrid Malaysian mahseer (Barbonymus gonionotus $q \times$ Tor tambroides $\delta$ ) during the larval development. Aquac Rep 15: 100210. DOI: 10.1016/j.aqrep.2019.100210.

Kenthao A, Jearranaiprepame P. 2020. Ecomorphological diversification of some barbs and carps (Cyprininae, Cyprinidae) in the Lower Mekong Basin of Thailand. Zoology 143: 125830. DOI: 10.1016/j.zool.2020.125830.

Kottelat M, Whitten AJ, Kartikasari SN, Wirjoatmodjo S. 1993. Freshwater Fishes of Western Indonesia and Sulawesi. Berkeley Book Pte. Ltd., Singapore.

Muchlisin ZA, Azizah MNS. 2009. Diversity and distribution of freshwater fishes in Aceh Waters, Northern Sumatra, Indonesia. Int J Zool Res 5: 62-79. DOI: 10.3923/ijzr.2009.62.79.

Muchlisin ZA, Batubara AS, Azizah MNS, Alim M, Hendri A, Fadli N, Muhammadar AA, Sugianto. 2015. Feeding habit and length-weight relationship of Keureling fish, Tor tambra (Valenciennes, 1842) (Cyprinidae) from the western region of Aceh Province, Indonesia. Biodiversitas 16 (1): 89-94. DOI: 10.13057/biodiv/d160112.

Nguyen TTT, de Silva SS. 2006. Freshwater finfish biodiversity and conservation: An Asian perspective. Biodivers Conserv 15: 35433568. DOI: 10.1007/s10531-005-0312-8.

Nurfadillah N, Desrita, Phonna BA, Defira CN. 2019. Analysis of food habits and length-weight relationships (LWRs) of java barb (Barbonymus gonionotus Bleeker) in Reubee River, Pidie, Aceh. ICFAES 2019. IOP Conf Ser Earth Environ Sci 348: 012081. DOI: 10.1088/1755-1315/348/1/012081.

Mondol MR, Dewan S, Hossain MA, Asaduzzaman M, Islam MA, Rozario UA. 2005. Food and feeding habits of Puntius gonionotus (Thai Sarpunti) in Rice Field. Pak J Biol Sci 8(3): 386-395. DOI: 10.3923/pjbs.2005.386.395.

Pulungan CP, Putra RM, Windarti, Deni E. 2007. Handbook of Fisheries Biology. Riau University, Pekanbaru. [Indonesian]

Rayhanu A, Junaidi E, Husnah. 2004. Feeding behavior of Asian Barb (Barbodes schwenenfeldii) in Kampar River, Riau Province. J Ilmuilmu Perikanan and Budidaya Perairan 2 (1): 47-60. [Indonesian]

Setiawan B. 2007. Reproductive biology and food habits of Lampam fish (Barbonymus schwanenfeldii) in Musi River, South Sumatra. IPB, Bogor. [Indonesian]

Syahputra H, Bakti D, Kurnia MR. 2014. Study of the dietary composition of raw sepat fish (Trichogaster trichopterus Pallas) in the Inundated Swamp of Marundal Village, Patumbak District. Aquacoastmarine 5 (4): 60-71. [Indonesian]

Wulandari D. 2009. The relationship between phytoplankton abundance and physical-chemical parameters in the estuary of Brantas River (Porong), East Java. IPB, Bogor. [Indonesian]

Yamaji IE. 1979. Illustration of the marine plankton of Japan. Hoikusha Publishing Co. Ltd., Osaka, Japan. 